\title{
Short- and long-term effects of maternal nicotine exposure during lactation on body adiposity, lipid profile, and thyroid function of rat offspring
}

\author{
E Oliveira ${ }^{1}$, E G Moura ${ }^{1}$, A P Santos-Silva ${ }^{1}$, A T S Fagundes ${ }^{1}$, A S Rios ${ }^{1}$, Y Abreu-Villaça ${ }^{1}$, \\ J F Nogueira Neto ${ }^{2}$, M C F Passos ${ }^{1,3}$ and P C Lisboa ${ }^{1}$ \\ ${ }^{1}$ Department of Physiological Sciences, Roberto Alcantara Gomes Biology Institute, ${ }^{2}$ Laboratory of Lipids, School of Medicine and ${ }^{3}$ Department of Applied \\ Nutrition, Nutrition Institute, State University of Rio de Janeiro, Rio de Janeiro 20551-030, Brazil \\ (Correspondence should be addressed to P C Lisboa; Email: pclisboa@uerj.br)
}

\begin{abstract}
Epidemiological studies show a higher prevalence of obesity in children from smoking mothers and smoking may affect human thyroid function. To evaluate the mechanism of smoking as an imprinting factor for these dysfunctions, we evaluated the programing effects of maternal nicotine (NIC) exposure during lactation. Two days after birth, osmotic minipumps were implanted in lactating rats, divided into: NIC $(6 \mathrm{mg} / \mathrm{kg}$ per day s.c.) for 14 days; Control - saline. All the significant data were $P<0.05$ or less. Body weight was increased from 165 days old onwards in NIC offspring. Both during exposure (at 15 days old) and in adulthood (180 days old), NIC group showed higher total fat (27 and $33 \%$ ). In addition, NIC offspring presented increased visceral fat and total body protein. Lipid profile was not
\end{abstract}

changed in adulthood. Leptinemia was higher at 15 and 180 days old (36 and 113\%), with no changes in food intake. Concerning the thyroid status, the 15-days-old NIC offspring showed lower serum-free tri-iodothyronine $\left(\mathrm{FT}_{3}\right)$ and thyroxine $\left(\mathrm{FT}_{4}\right)$ with higher TSH. The 180-days-old NIC offspring exhibited lower TSH, $\mathrm{FT}_{3}$, and $\mathrm{FT}_{4}$ ). In both periods, liver type 1 deiodinase was lower (26 and 55\%). We evidenced that NIC imprints a neonatal thyroid dysfunction and programs for a higher adiposity, hyperleptinemia, and secondary hypothyroidism in adulthood. Our study identifies lactation as a critical period to NIC programing for obesity, with hypothyroidism being a possible contributing factor.

Journal of Endocrinology (2009) 202, 397-405

\section{Introduction}

Several epidemiological and animal studies have shown that malnutrition, hormones, and other stressful events during critical periods of early life permanently alter the function of the body's systems of the progeny. This association has been named programing, which is defined as the phenomenon that putatively underlies relationships among nutritional experiences of early life and adult diseases (Lucas 1994, Barker 2003, Moura \& Passos 2005, de Moura et al. 2008).

Some environmental and dietary chemicals that can mimic or interfere with the normal action of hormones are referred to as 'endocrine disruptors'. Additional studies predict the existence of chemical 'obesogens', molecules that inappropriately regulate lipid metabolism and adipogenesis to promote obesity (Grun \& Blumberg 2006, Tabb \& Blumberg 2006).

During pregnancy, cigarette smoking causes low birth weight (Butler \& Goldstein 1973, Navarro et al. 1989, DiFranza \& Lew 1995), and epidemiological studies suggest that maternal smoking during pregnancy might be a risk factor for childhood obesity (Morley et al. 1995, Vik et al. 1996, Blake et al. 2000, von Kries et al. 2002, Toschke et al. 2002, Bergmann et al. 2003, Wideroe et al. 2003, Goldani et al. 2007); however, the mechanisms to explain the development of obesity are still unclear.

Newman et al. (1999) observed that rats exposed to nicotine (NIC), the main addictive compound of tobacco smoke, in utero, are heavier at 9 weeks old when compared with controls. Williams \& Kanagasabai (1984) reported that fetal NIC exposure in rats increases body fat in the fetus on the 20th day of gestation (term on the 21st day), suggesting that fetal NIC exposure results in increased adiposity in the offspring.

Only few studies suggest that the first postnatal week is critical for NIC programing of body weight (BW) and body fat distribution. NIC exposure in rats, extending from the gestational period to the 10th day of lactation, increases $\mathrm{BW}$ in offspring at 35 days old. In male offspring, this effect is transient, but in females the higher BW persists until 90 days of age (Chen \& Kelly 2005). Additionally, rats whose mothers were treated with NIC for 14 days before mating and during 
pregnancy until weaning become heavier at 70 days old when compared with the control group. At 6 months of age, NIC exposure results in increased $\mathrm{BW}$, fat pad weight, and perivascular adipose tissue in the offspring (Gao et al. 2005).

Increased body fat/weight is associated with enhanced levels of the adipocyte hormone, leptin (Friedman \& Halaas 1998). However, the association between smoking and leptin levels is controversial. In tobacco smokers, both hyperleptinemia (Hodge et al. 1997, Eliasson \& Smith 1999, Nicklas et al. 1999) and hypoleptinemia (Wei et al. 1997, Donahue et al. 1999) have been described.

Smoking can also affect the thyroid gland (Christensen et al. 1984, Ericsson \& Lindgrade 1991, Fisher et al. 1997, Utiger 1998). Although there is less data on the effect of tobacco compounds upon the thyroid, thiocyanate, but not NIC, is associated with hypothyroidism (Muller et al. 1995, Fukata et al. 1996). In addition, maternal smoking influences the thyroid function in infants (Meberg \& Marstein 1986, Karakaya et al. 1987, Chanoine et al. 1991). Passive smoking from both parents affects thyroid function. Thyroglobulin and thiocyanate concentrations at birth and at 1 year of age in infants whose parents are smokers are greater than in infants with nonsmoking parents (Gasparoni et al. 1998). According to Lauberg et al. (2004), smoking mothers have lower iodide content in breast milk and their offspring have lower urinary iodide. This study suggests that NIC decreases maternal milk iodide transfer.

Our group has been working with several imprinting factors during lactation that are capable of programing the hormonal regulation and body composition (Passos et al. 2002, 2004, Dutra et al. 2003, Vicente et al. 2004, Toste et al. 2006a,b, Fagundes et al. 2007, de Moura et al. 2007). Particularly, maternal nutritional and hormonal changes during the lactation period in rats were shown to program the thyroid function in adult life (Passos et al. 2002, 2007, Dutra et al. 2003, Lins et al. 2005, Bonomo et al. 2008, Lisboa et al. 2008). Since thyroid dysfunction is associated with marked changes on both energy expenditure and BW (Pontikides \& Krassas 2007), it is interesting to evaluate the thyroid status in the model of programing by maternal NIC exposure during lactation. In addition, it seems likely that thyroid hormones and leptin play mutual roles (Ahima et al. 1996, Escobar-Morreale et al. 1997, Ortiga-Carvalho et al. 2002, Rosenbaum et al. 2002, Oliveira et al. 2007, De Oliveira et al. 2007).

Despite experimental evidence of NIC programing during gestation and also when the exposure extends from pregnancy to lactation, to our knowledge, there are no studies focusing on the effects of NIC exposure exclusively during the early postnatal period. This may be of particular relevance since there is a high rate of smoking relapse among women who stop smoking during pregnancy (McBride \& Pirie 1990). Thus, our aim was to evaluate the short- and long-term consequences of maternal NIC exposure, solely during lactation, on BW, body composition, serum leptin, and thyroid function of rat offspring at different ages. Since there is an association between higher visceral fat mass (VFM) and other components of the metabolic syndrome, such as dyslipidemia, we also studied the lipid profile of the NIC-treated animals.

\section{Materials and Methods}

Wistar rats were kept in a temperature-controlled room $\left(25 \pm 1{ }^{\circ} \mathrm{C}\right)$ with artificial darkness-light cycles (lights on at $0700 \mathrm{~h}$ and lights off at $1900 \mathrm{~h}$ ). Virgin female rats 3 months of age were caged with male rats in the proportion of $3: 1$. After mating, each female was placed in an individual cage with free access to water and food until delivery. The use of the animals according to our experimental design was approved by the Animal Care and Use Committee of the Biology Institute of the State University of Rio de Janeiro (CEA/189/2007), which based its analysis on the principles described in the Guide for the Care and Use of Laboratory Animals (Bayne 1996).

\section{Experimental model of maternal NIC exposure during lactation}

Two days after birth, 12 lactating rats were randomly assigned to one of the following groups:

NIC $(n=6)$ - dams were lightly anesthetized with thiopental, a $3 \times 6 \mathrm{~cm}$ area on the back was shaved, and an incision made to permit s.c. insertion of osmotic minipumps (Alzet, 2ML2, Los Angeles, CA, USA). Pumps were prepared with NIC-free base diluted in a saline solution $(\mathrm{NaCl} 0.9 \%)$ to deliver an initial dose rate of $6 \mathrm{mg} / \mathrm{kg}$ of NIC per day (during 14 days of lactation), as previously described (Abreu-Villaca et al. 2004a,b). At this dose rate, this paradigm produces plasma NIC levels similar to those in typical smokers - $\sim 25 \mathrm{ng} / \mathrm{ml}$ (Lichtensteiger et al. 1988). The incision was closed and the mothers were permitted to recover in their home cages. Control (C, $n=6)$ - dams were implanted with osmotic minipumps containing only saline solution, released for the same period as that of minipumps with NIC.

Generally, pregnant rats produced 10-12 pups and, to avoid the influence of the litter size in the programing effect, we only used mothers whose litter size was 10 offspring. At birth, litter adjustment was performed and six male pups were kept per NIC or C mother to maximize the lactation performance.

During lactation, BW (mothers and pups) and relative food intake $(\mathrm{g} / 100 \mathrm{~g} \mathrm{BW})$ of the mothers were daily monitored. From weaning (21 days of lactation) until 180 days, BW of the offspring was monitored every 4 days and relative food intake was monitored every 15 days.

We used two offspring from each mother at each age point (12 rats per group). The experiment was performed twice: at the first, offspring were killed at 15, 21, and 180 days old; and at the second, offspring were killed at 15, 90, and 180 days old. The killing occurred by decapitation to collect blood, VFM, and carcass. 
Body composition

After the killing, VFM was quickly excised and weighed for evaluation of the central adiposity - mesenteric, epidydimal, and retroperitoneal (Toste et al. 2006a, Fagundes et al. 2007), and data were expressed as $\mathrm{g} / 100 \mathrm{~g} \mathrm{BW}$.

Body composition (total fat and protein mass) was determined by carcass analysis (Toste et al. 2006a, Fagundes et al. 2007). NIC and C offspring were eviscerated; the carcasses were weighed, autoclaved for $1 \mathrm{~h}$, and homogenized in distilled water $(1: 1)$. The homogenates were stored at $4{ }^{\circ} \mathrm{C}$ for analysis.

Homogenates ( $3 \mathrm{~g}$ ) were used to determine fat content gravimetrically. Samples were hydrolyzed in a shaking water bath at $70{ }^{\circ} \mathrm{C}$ for $2 \mathrm{~h}$ with $30 \% \mathrm{KOH}$ and ethanol. The total fatty acids and nonesterified cholesterol were removed with three successive washings with petroleum ether. After drying overnight in vacuum, all tubes were weighed and data were expressed as $\mathrm{g}$ fat/100 $\mathrm{g}$ carcass.

Protein content was determined in $1 \mathrm{~g}$ homogenates. Tubes were centrifuged at $2000 \mathrm{~g}$ for $10 \mathrm{~min}$. The total protein concentrations were determined by the Lowry method (Lowry et al. 1951). Data were expressed as $\mathrm{g}$ protein/100 g carcass.

\section{Lipid profile}

Serum levels of total cholesterol (TC), triglycerides (TG), high-density lipoprotein (HDL), low-density lipoprotein (LDL), and very-low-density lipoprotein (VLDL) were analyzed in the adult offspring using Biosystem commercial test kits (Simões et al. 2007).

LDL-C and VLDL-C were obtained using Friedewald calculations:

1) $\mathrm{LDL}-\mathrm{C}(\mathrm{mg} / \mathrm{dl})=\mathrm{TC}-(\mathrm{TG} / 5)-\mathrm{HDL}-\mathrm{C}$.

2) $\operatorname{VLDL}-\mathrm{C}(\mathrm{mg} / \mathrm{dl})=\mathrm{TG} / 5$.

\section{Hormones determination by RIA}

Blood samples were centrifuged $\left(1500 \mathrm{~g} / 20 \mathrm{~min} / 4^{\circ} \mathrm{C}\right)$ to obtain serum and were individually kept at $-20{ }^{\circ} \mathrm{C}$ until assay. All measurements for each hormone were performed in one assay.

Leptin was measured by specific RIA kit (Linco Research, Inc., St. Charles, MO, USA), which measures both rat and mouse leptin with a range of detection from 0.5 to $50 \mathrm{ng} / \mathrm{ml}$; the intra-assay variation was $2 \cdot 9 \%$.

Free thyroid hormones (free tri-iodothyronine $\left(\mathrm{FT}_{3}\right)$ and thyroxine $\left(\mathrm{FT}_{4}\right)$ ) were determined by commercial RIA kit (ICN Pharmaceuticals, Inc., Costa Mesa, CA, USA) with an assay sensitivity of $0.045 \mathrm{ng} / \mathrm{dl}\left(\mathrm{T}_{4}\right)$ and $0.06 \mathrm{pg} / \mathrm{ml}\left(\mathrm{T}_{3}\right)$. The intra-assay variation was $2 \cdot 8 \%\left(\mathrm{~T}_{4}\right)$ and $3 \cdot 6 \%\left(\mathrm{~T}_{3}\right)$.

TSH was measured by specific RIA, using a rat TSH kit supplied by the National Institute of Health (NIH, USA) and expressed in terms of the reference preparation provided (RP-3). The intra-assay variation was $2 \cdot 3 \%$, with $0 \cdot 18 \mathrm{ng} / \mathrm{ml}$ as the lower limit of detection.

\section{Liver D1 activity determination}

In order to confirm the thyroid status, liver D1 activity of 15 and 180 days old offspring was measured in the microsomes by the release of ${ }^{125} \mathrm{I}$ from ${ }^{125} \mathrm{I}$-reverse $\mathrm{T}_{3}\left(\mathrm{rT}_{3}\right)$, as previously reported (Lisboa et al. 2003). Assay was performed in phosphate buffer containing $1 \mathrm{mM}$ EDTA ( $\mathrm{pH} \mathrm{6.9)}$ in the

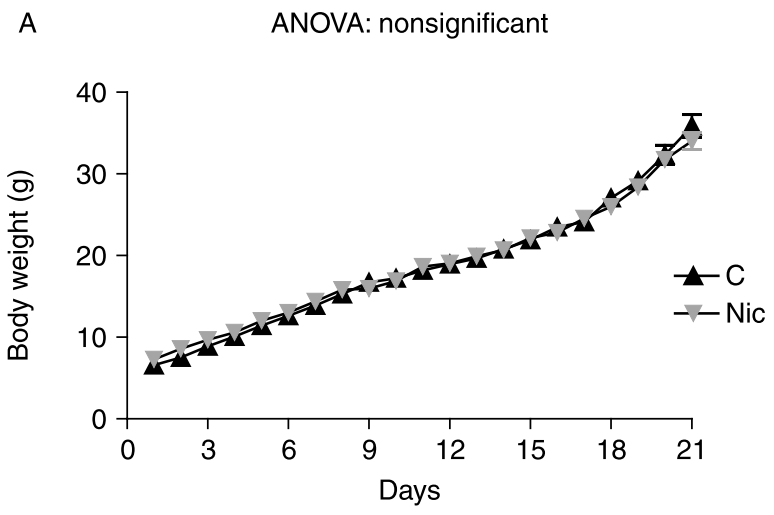

B ANOVA: treatment $(P<0.0001)$

Treatment $\times$ age $(P<0.0001)$
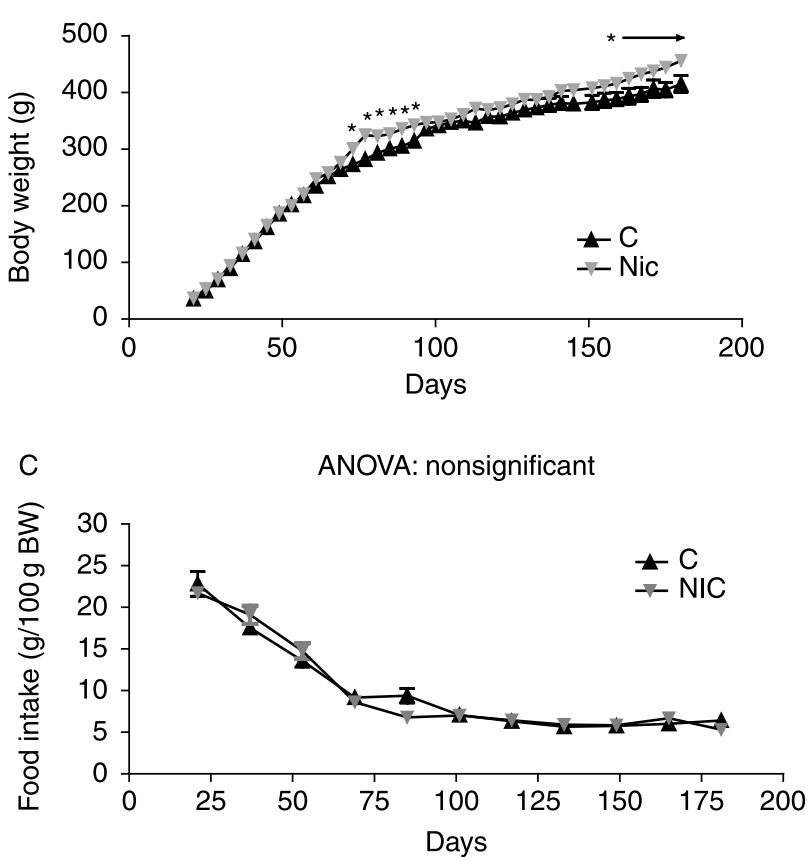

Figure 1 Body weight during lactation (A), after weaning (B), and food intake $(C)$ of offspring whose mothers were nicotine (gray) or saline (black) exposed during lactation. Values represent mean \pm S.E.M. of 12 rats per group. $* P<0 \cdot 05$ versus $C$. 
presence of $1.5 \mu \mathrm{M} \mathrm{rT}$ and $10 \mathrm{mM}$ dithiothreitol. Free ${ }^{125} \mathrm{I}$ of enzymatic deiodination was eluted from Dowex $50 \mathrm{~W}-\mathrm{X} 2$ columns (Bio-Rad, EUA) with 10\% acetic acid. Deiodination percentual in the presence of the enzyme was around $10-20 \%$. Amount of free ${ }^{125} \mathrm{I}$ in blank was $<1-2 \%$ of the total radioactivity in the reaction mixture. Specific enzyme activity was expressed by nanomoles of $\mathrm{rT}_{3}$ deiodinated/ $\mathrm{h} \times \mathrm{mg}$ of protein.

\section{Statistical analysis}

Results were reported as mean \pm s.E.M. The GraphPad Prism 4 and Statview $5 \cdot 0$ programs were used for statistical analyses and graphics. Initially, two-way ANOVA on each variable (BW and food intake evolutions, total body fat, protein content, leptin, $\mathrm{FT}_{3}, \mathrm{FT}_{4}, \mathrm{TSH}$, and D1) were carried out. Treatment and age were used as between-subjects factors. Whenever this initial test indicated treatment effects that differed among the different ages, data were then re-examined separately using one-way ANOVAs; however, where treatment effects did not interact with age, only the main effect was recorded without testing of individual differences. TC, TG, HDL, LDL, and VLDL data were analyzed by Student unpaired $t$-test. Differences were considered significant at $P<0 \cdot 05$.

\section{Results}

During NIC exposure, NIC mothers had no BW and food intake change compared with the $\mathrm{C}$ group. Maternal NIC exposure did not change BW gain of the offspring during lactation (Fig. 1A). However, after weaning, NIC offspring presented higher BW compared with $\mathrm{C}$ offspring (treatment: $\left.F_{1,1475}=111 \cdot 4, P<0 \cdot 0001\right)$, an effect that was dependent on the age (treatment $\times$ age: $\left.F_{39,1475}=2 \cdot 4, P<0 \cdot 0001\right)$. Accordingly, data were subdivided into separate ages for further analysis. After subdivision, we found higher BW for NIC offspring between 75 and 100 days of life (around 10\%, $P<0 \cdot 05)$ as well as after 165 days old, reaching $10 \%(P<0 \cdot 05)$ at 180 days old (Fig. 1B). We did not observe food intake alterations during the entire experimental period, as depicted in Fig. 1C.

Body composition of the offspring is shown in Fig. 2. NIC treatment affected body fat mass (treatment: $F_{1,56}=9 \cdot 6$, $P<0.004)$ and the effects were age dependent (treatment $X$ age: $\left.F_{3,56}=3 \cdot 4, P<0 \cdot 03\right)$ : NIC offspring showed higher total fat mass on the 15 th day of lactation ( $+27 \%$ : Fig. $2 \mathrm{~A}$, $P<0 \cdot 003)$, at $90(+25 \%$ : Fig. $2 \mathrm{~A}, P<0 \cdot 02)$, and at 180 days old (+33\%: Fig. 2A, $P<0 \cdot 05)$ days old. VFM (Fig. $2 \mathrm{~B}$ ) and total protein content (Fig. 2C) also differed between treatment groups (treatment: $F_{1,68}=7 \cdot 8, P<0.006$ and treatment: $F_{1,56}=4 \cdot 6, P<0 \cdot 04$ respectively); however, there were no treatment $X$ age interactions. Accordingly, across the four analyzed ages, NIC elicited increased values for VFM and total protein content when compared with $\mathrm{C}$ offspring.

Treatment caused hyperleptinemia (treatment: $F_{1,58}=7 \cdot 6$, $P<0 \cdot 008)$ and the effects were age dependent (treatment
Xage: $\left.F_{3,58}=3 \cdot 1, P<0 \cdot 04\right)$. Separate analyses for each age demonstrated a trend towards significance at 15 days $(+36 \%$ - treatment: $\left.F_{1,11}=4 \cdot 4, P<0 \cdot 06\right)$ and a significant increase at $180\left(+113 \%\right.$ - treatment: $\left.F_{1,18}=9 \cdot 3, P<0 \cdot 007\right)$ days in offspring whose mothers were NIC exposed during lactation, as shown in Fig. 3. NIC offspring presented no change in lipid profile when they were 180 days old (Table 1).

Figure 4 shows the thyroid function of animals whose mothers were NIC or saline exposed. NIC treatment affected $\mathrm{FT}_{3}$ (treatment: $F_{1,51}=9 \cdot 7, P<0 \cdot 004$ ), so that NIC offspring
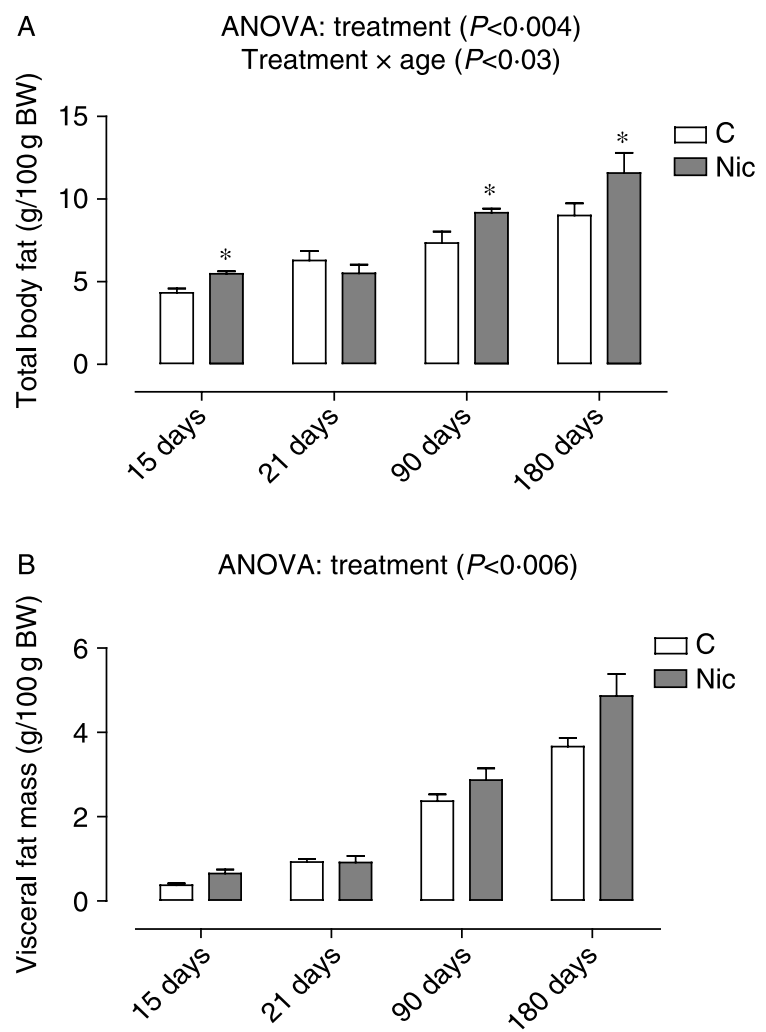

C ANOVA: treatment $(P<0.04)$

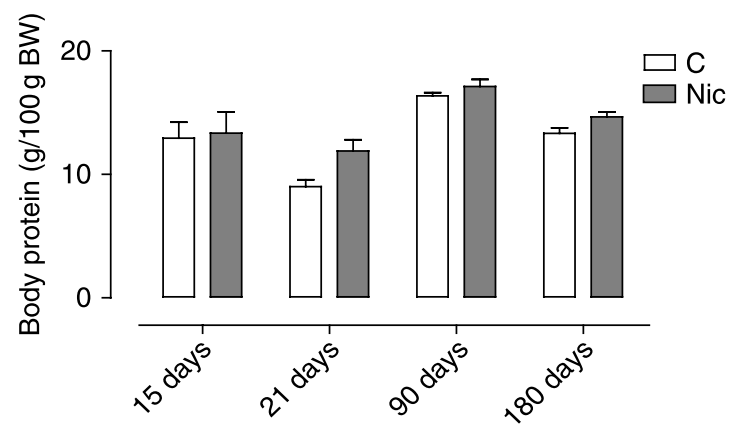

Figure 2 Body total fat mass (A), visceral fat mass (B), and body total protein mass (C) at 15,21,90, and 180-days-old offspring whose mothers were nicotine or saline exposed during lactation. Values represent mean \pm S.E.M. of $6-12$ rats per group. ${ }^{*} P<0 \cdot 05$ versus $C$. 


\section{ANOVA: treatment $(P<0.008)$ \\ Treatment $\times$ age $(P<0.04)$}

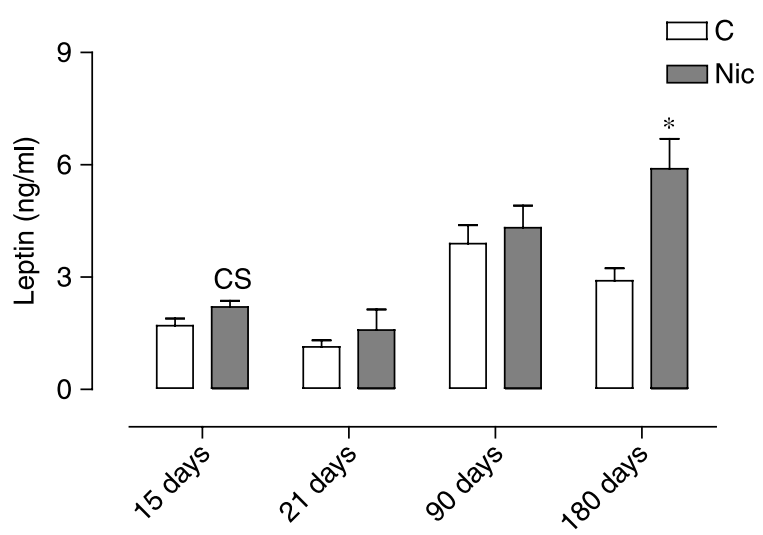

Figure 3 Serum leptin at 15, 21, 90, and 180-days-old offspring whose mothers were nicotine or saline exposed during lactation. Values represent mean \pm S.E.M. of $6-12$ rats per group; CS, close to significance. ${ }^{*} P<0 \cdot 05$ versus $C$.

presented lower serum $\mathrm{FT}_{3}$ when compared with $\mathrm{C}$ rats, an effect that was largely determined by differences between NIC and C offspring at 15, 21, and 180 days (Fig. 4A). As for $\mathrm{FT}_{4}$ (treatment: $F_{1,62}=8 \cdot 2, \quad P<0 \cdot 006$; treatment $\times$ age: $\left.F_{3,62}=3 \cdot 1, P<0 \cdot 0001\right)$, decreased values for NIC offspring reached significance in 15 days $\left(-31 \%\right.$ - treatment: $F_{1,18}$ $=53 \cdot 3, P<0 \cdot 0001)$ and $180\left(-15 \%-\right.$ treatment: $F_{1,14}=7 \cdot 7$, $P<0 \cdot 02$ ) days old offspring (Fig. 4B). NIC treatment also affected TSH (treatment: $F_{1,53}=7 \cdot 7, P<0 \cdot 008$; treatment $X$ age: $\left.F_{3,53}=6 \cdot 5, P<0 \cdot 0008\right)$. The 15 -days-old NIC pups presented higher TSH $\left(F_{1,12}=5 \cdot 3, P<0 \cdot 04\right)$. In contrast, at $21\left(F_{1,11}=5 \cdot 7, P<0 \cdot 04\right), 90 \quad\left(F_{1,14}=9 \cdot 4, \quad P<0 \cdot 009\right)$, and $180\left(F_{1,16}=6 \cdot 2, P<0 \cdot 02\right)$ days, lower TSH in NIC offspring reached significance (Fig. 4C). NIC offspring presented lower liver D1 activity (treatment: $F_{1,29}=31 \cdot 4$, $P<0 \cdot 0001$; treatment $\times$ age: $\left.F_{1,29}=7 \cdot 1, P<0 \cdot 02\right)$ on 15 days $\left(-26 \%\right.$ - treatment: $\left.F_{1,13}=4 \cdot 8, P<0 \cdot 05\right)$ and 180 days $\left(-55 \%\right.$ - treatment: $F_{1,29}=33 \cdot 0, P<0 \cdot 0001$; Fig. $\left.4 \mathrm{D}\right)$.

Table 1 Lipid profile of adult rats whose mothers received nicotine during lactation. Values represent mean \pm s.E.M. of 6-12 rats per group.

\section{0 days-old offspring}

\begin{tabular}{|c|c|}
\hline Control & Nicotine \\
\hline $59 \cdot 1 \pm 1 \cdot 9$ & $53 \cdot 3 \pm 3 \cdot 1$ \\
\hline $12 \cdot 7 \pm 0 \cdot 8$ & $13 \cdot 8 \pm 1 \cdot 1$ \\
\hline $33 \cdot 6 \pm 1 \cdot 9$ & $32 \cdot 5 \pm 3 \cdot 4$ \\
\hline $12 \cdot 8 \pm 1 \cdot 1$ & $14 \cdot 8 \pm 4 \cdot 8$ \\
\hline $64 \cdot 1 \pm 5 \cdot 6$ & $50 \cdot 6 \pm 2 \cdot 9$ \\
\hline
\end{tabular}

TC, total cholesterol; HDL-C, high-density lipoprotein cholesterol; LDL-C, low-density lipoprotein cholesterol; VLDL-C, very low-density lipoproteins; TG, triglycerides.

\section{Discussion}

Previous studies have demonstrated that there is a high prevalence of women who do not ever quit smoking during pregnancy or lactation (O'Campo et al. 1992). However, there is a high rate of smoking relapse among women who stopped smoking during pregnancy (McBride \& Pirie 1990). Despite this fact, the majority of epidemiological studies on maternal smoking and experimental data on NIC exposure were observed during pregnancy or pregnancy and lactation.

In our study, for the first time, it was evidenced that in rats maternal NIC exposure, only during lactation, causes neonatal thyroid hypofunction and programs for overweight, hyperleptinemia, and lower function of the pituitary-thyroid axis later in the offspring life. In fact, lactation is a critical period of life, as in this phase important cognitive and neurological development occurs, which suggests that adverse environmental changes can cause physiological modifications that predispose the development of some diseases in adulthood (Mott et al. 1991, Symonds 2007).

In rodents, NIC exposure during pregnancy does not alter the BW gain of the mothers (Chen \& Kelly 2005). However, experimental studies have documented an inverse relationship between cigarette smoking and $\mathrm{BW}$, showing that cessation of NIC exposure is usually accompanied by weight gain (Levine et al. 1987). According to Li et al. (2000), adult rats exposed to NIC reduce BW and are hypophagic. Despite these previous data, in the present study, NIC exposure from the 2nd to the 14th day of lactation did not affect the mother's BW gain or food intake. Since during lactation many mechanisms are activated in order to supply the high energy requirement, including hyperphagia, basal metabolic rate reduction, and preferential nutrient flux for lactogenesis (Dewey 1998), it is possible that during this particular phase, these mentioned events are more important and counterbalance the wellknown effects of NIC in nonlactating animals.

In previous experimental studies, pre- and postnatal NIC exposure failed to cause changes in $\mathrm{BW}$ during the exposure period (Chen \& Kelly 2005, Gao et al. 2005). Interestingly, in our study, despite the fact that NIC exposure did not affect $\mathrm{BW}$ gain of NIC offspring during lactation, these rats showed greater total and VFM when they were 15 days old, when they were still being exposed to NIC.

Some studies have shown that there is an increased risk of obesity in children whose mothers smoked during pregnancy (Vik et al. 1996, von Kries et al. 2002). Our data showed maternal NIC exposure during lactation programs for higher VFM, total body fat, and protein content in adulthood. These alterations in body composition may be responsible for the higher BW of NIC offspring. These programed rats did not show food intake changes, which suggest the development of a hypometabolic status. Chen \& Kelly (2005) showed that NIC treatment during pregnancy and for the first 10 days of life affected $\mathrm{BW}$ with sex-dependent changes. BW was significantly higher on 35,63 , and 90 days old, in female rats. 
A

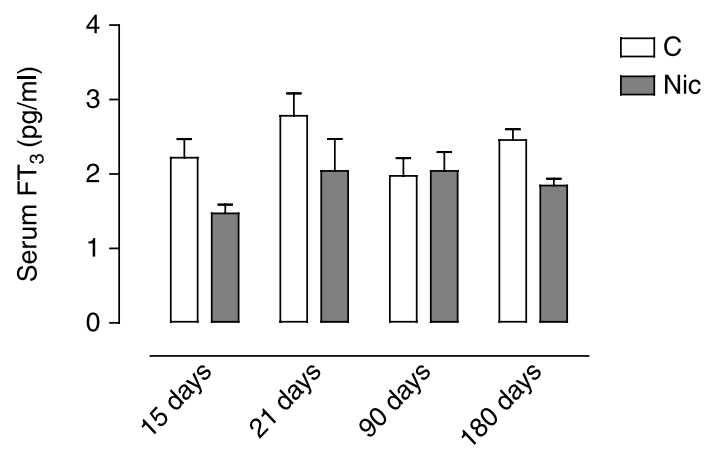

B

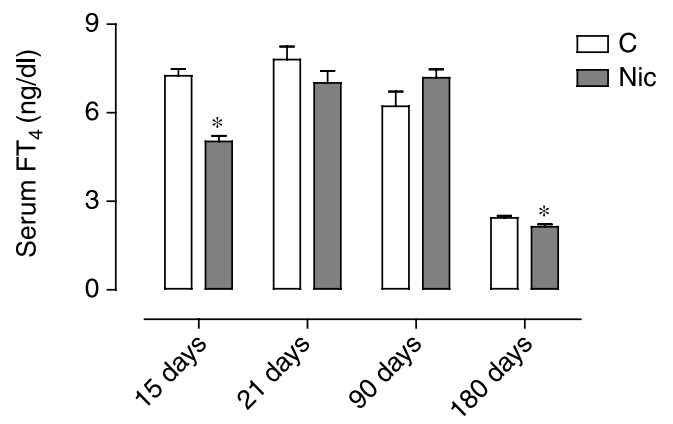

C ANOVA: treatment $(P<0.008)$

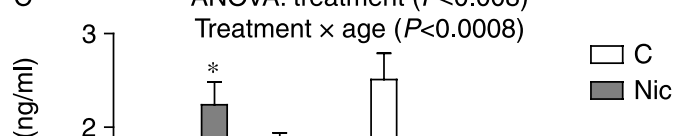

Treatment $(P<0.006)$ Treatment $\times$ age $(P<0.0001)$ B

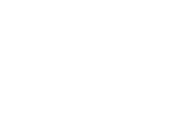

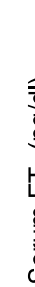


offspring stimulate muscle protein synthesis through GH action, resulting in the higher amount of total body protein content.

Concerning thyroid status, as previously mentioned, we have detected that maternal NIC exposure only during lactation leads to lower thyroid hormone serum concentration in young and adult offspring. This lower serum hormone concentration seems to cause a hypofunction that was confirmed by the lower liver D1 activity on NIC offspring at 15 and 180 days old, since this enzyme activity and/or expression is considered a marker of thyroid status that is decreased in hypothyroidism and increased in hyperthyroidism (Bianco \& Kim 2006). In rats, NIC exposure extending from the gestational period to the 10th day of lactation did not change serum thyroid hormones at 10-daysold offspring (Chen \& Kelly 2005). However, these authors did not study the thyroid hormones profile in other periods of life. The higher total and central body fat mass of young and adult NIC offspring may be due, at least in part, to their possible hypothyroidism. An earlier adiposity has been reported in children with congenital hypothyroidism, suggesting that thyroid dysfunction during fetal and neonatal life affects body mass index during the first years of life (Livadas et al. 2007).

Some studies have shown changes in thyroglobulin, thyroid hormones, TSH, and goiter caused by tobacco (Christensen et al. 1984, Ericsson \& Lindgrade 1991, Muller et al. 1995, Fisher et al. 1997, Utiger 1998). There are several mechanisms by which smoking can affect thyroid hormone levels. Tobacco smoke contains thiocyanate that has been shown to be a potential anti-thyroid factor (Meberg \& Marstein 1986, Dai et al. 1996, Lauberg et al. 2004). Our findings showed that early NIC exposure causes a transient thyroid dysfunction during lactation. NIC pups presented lower thyroid hormones and higher TSH at 15 days old, suggesting a primary thyroid hypofunction in neonatal life. After NIC withdrawal, weaned pups presented normal serum $\mathrm{T}_{4}$; however, $\mathrm{TSH}$ and $\mathrm{T}_{3}$ levels were lower. In a similar way to the thiocyanate (Perron et al. 2001, Lauberg et al. 2004), it is possible that NIC inhibits the mammary sodium iodide symporter, reducing the supply of iodine to pups during lactation causing hypothyroidism, which was partially corrected by the absence of NIC, at weaning.

Neonatal NIC treatment programs for lower serum TSH in 90-days-old offspring. At 180-days-old, we found lower serum TSH and thyroid hormones concentrations. Both $\mathrm{FT}_{3}$ and $\mathrm{FT}_{4}$ are in the lower normal ranges, when we compared with a large sample of $\mathrm{FT}_{3}$ and $\mathrm{FT}_{4}$ of rat controls at the same age from different experiments of our laboratory (data not shown). However, for TSH, all of the NIC values were lower than the $10 \%$ lowest control values, suggesting a truly thyrotroph hypofunction. These findings suggest the development of extra-thyroidal dysfunction of adult NIC offspring confirmed by lower TSH levels since weaning. The mechanism for this event is still unclear, but it is possible that maternal NIC exposure caused a central hypothyroidism, induced by a hypothalamic-pituitary dysfunction, with reduced thyrotropin-releasing hormone (TRH)-TSH production and/or release or TRH action on the pituitary.

In the present study, we can not explain whether the effect of programing by maternal NIC exposure is caused by a direct or indirect NIC action. There are, at least, three hypotheses to explain the NIC effects in our experimental model. First, NIC transfer through maternal milk (Dahlstrom et al. 1990, Narayanan et al. 2002) may change some factor(s) in offspring. Second, maternal alterations caused by NIC treatment, for example, hormonal changes, may be transferred through the milk to the pups. And finally, the programing by NIC exposure can result from both mothers and pups functional changes.

In conclusion, we have demonstrated that maternal NIC exposure, exclusively during lactation, programs for a higher BW gain and adiposity in adult life of the offspring as well as for hyperleptinemia. In addition, early NIC exposure possibly leads to a neonatal thyroid hypofunction and programs for central hypothyroidism, which may partially explain the overweight at adulthood. Then, NIC can be one of the tobacco compounds responsible for the thyroid dysfunctions, and maternal smoking may be considered an important risk factor for the development of thyroid diseases in offspring. Altogether, our present data evidence how the events caused by early NIC exposure only during the critical period of lactation are complex and capable of changing the future development of the offspring, possibly acting as an endocrine disruptor and an obesogen factor. Furthermore, the higher adiposity detected in our model may help to explain the prevalence of obesity in children exposed to cigarette smoke during the perinatal period.

\section{Declaration of interest}

The authors declare no conflict of interest.

\section{Funding}

This research was supported by the "Thyroid Department of the Brazilian Society of Endocrinology and Metabolism' (Departamento de Tireóide da Sociedade Brasileira de Endocrinologia e Metabologia), the "National Council for Scientific and Technological Development' (Conselho Nacional de Desenvolvimento Científico e Tecnológico - CNPq), the 'Carlos Chagas Filho Research Foundation of the State of Rio de Janeiro' (Fundação Carlos Chagas Filho de Amparo à Pesquisa do Estado do Rio de Janeiro - FAPERJ), and Coordination for the Enhancement of Higher Education Personnel (Coordenação de Aperfeiçoamento de Pessoal de Nível Superior - CAPES). E O and A P S-S were recipients of FAPERJ fellowships (Bolsa nota 10). A T S F and A S R were recipients of CNPq fellowships.

\section{Acknowledgements}

All authors are grateful to Antonio C M de Sá, Vania Pinto, and Ana Maria B Coutinho from Laboratory of Lipids (LabLip, UERJ) for their lipid profile determination. We also thank Mr Carlos Roberto, Miss Monica Moura, and Mr Luciano Santos for their technical assistance. 


\section{References}

Abd el Mohsen MM, Fahim AT, Motawi TM \& Ismail NA 1997 Nicotine and stress: effect on sex hormones and lipid profile in female rats. Pharmacological Research 35 181-187.

Abreu-Villaca Y, Seidler FJ \& Slotkin TA 2004a Does prenatal nicotine exposure sensitize the brain tonicotine-induced neurotoxicity in adolescence? Neuropsychopharmacology 29 1440-1450.

Abreu-Villaca Y, Seidler FJ, Tate CA, Cousins MM \& Slotkin TA $2004 b$ Prenatal nicotine exposure alters the response to nicotine administration in adolescence: effects on cholinergic systems during exposure and withdrawal. Neuropsychopharmacology 29 879-890.

Ahima RS 2005 Central actions of adipocyte hormones. Trends in Endocrinology and Metabolism 6 307-313.

Ahima RS, Prabakaran D, Mantzoros C, Qu D, Lowell B, Maratos-Flier E \& Flier SJ 1996 Role of leptin in the neuroendocrine response to fasting. Nature 382 250-252.

Barker DJ 2003 The developmental origins of adult disease. European Journal of Epidemiology 18 733-736.

Bayne K 1996 Revised guide for the care and use of laboratory animals available. American Physiological Society. Physiologist 39 208-211.

Bergmann KE, Bergmann RL, Von Kries R, Bohm O, Richter R, Dudenhausen JW \& Wahn U 2003 Early determinants of childhood overweight and adiposity in a birth cohort study: role of breast-feeding. International Journal of Obesity and Related Metabolic Disorders 27 162-172.

Bianco AC \& Kim BW 2006 Deiodinases: implications of the local control of thyroid hormone action. Journal of Clinical Investigation 116 2571-2579.

Blake KV, Gurrin LC, Evans SF, Beilin LJ, Landau LI, Stanley FJ \& Newnham JP 2000 Maternal cigarette smoking during pregnancy, low birth weight and subsequent blood pressure in early childhood. Early Human Development 57 137-147.

Bonomo IT, Lisboa PC, Pereira AR, Passos MC \& de Moura EG 2007 Prolactin inhibition in dams during lactation programs for overweight and leptin resistance in adult offspring. Journal of Endocrinology 192 339-344.

Bonomo IT, Lisboa PC, Passos MC, Alves SB, Reis AM \& de Moura EG 2008 Prolactin inhibition at the end of lactation programs for a central hypothyroidism in adult rat. Journal of Endocrinology 198 331-337.

Butler NR \& Goldstein H 1973 Smoking in pregnancy and subsequent child development. BMJ 8 573-575.

Casanueva FF \& Dieguez C 1998 Interaction between body composition, leptin and growth hormone status. Baillière's Clinical Endocrinology and Metabolism 12 297-314.

Ceddia RB, William WN Jr \& Curi R 2001 The response of skeletal muscle to leptin. Frontiers in Bioscience 6 90-97.

Chanoine JP, Toppet V, Bourdoux P, Spehl M \& Delange F 1991 Smoking during pregnancy: a significant cause of neonatal thyroid enlargement. British Journal of Obstetrics and Gynaecology 98 65-68.

Chen WJ \& Kelly RB 2005 Effect of prenatal or perinatal nicotine exposure on neonatal thyroid status and offspring growth in rats. Life Sciences $\mathbf{7 6}$ $1249-1258$.

Christensen SB, Ericsson UB, Janzon L, Tibblin S \& Melander A 1984 Influence of cigarette smoking on goiter formation, thyroglobulin, and thyroid hormone levels in women. Journal of Clinical Endocrinology and Metabolism 58 615-618.

Dahlstrom A, Lundell B, Curvall M \& Thapper L 1990 Nicotine and cotinine concentrations in the nursing mother and her infant. Acta Paediatrica Scandinavica 79 142-147.

Dai Z, Gao J, An K, Lee JM, Edwards GE \& An G 1996 Promoter elements controlling developmental and environmental regulation of a tobacco ribosomal protein gene L34. Plant Molecular Biology 32 1055-1065.

Dewey KG 1998 Maternal body composition, caloric restriction and exercise during lactation. Journal of Nutrition 128 379S-380S.

DiFranza JR \& Lew RA 1995 Effect of maternal cigarette smoking on pregnancy complications and sudden infant death syndrome. Journal of Family Practice 40 385-394.

Donahue RP, Zimmet P, Bean JA, Decourten M, DeCarlo Donahue RA, Collier G, Goldberg RB, Prineas RJ, Skyler J \& Schneiderman N 1999
Cigarette smoking, alcohol use, and physiological activity in relation to serum leptin levels in a multiethnic population: the Miami Community Health Study. Annals of Epidemiology 9 108-113.

Dutra SC, Passos MC, Lisboa PC, Santos RS, Cabanelas AP, Pazos-Moura CC \& Moura EG 2003 Liver deiodinase activity is increased in adult rats whose mothers were submitted to malnutrition during lactation. Hormone and Metabolic Research 35 268-270.

Eliasson B \& Smith U 1999 Leptin levels in smokers and long-term users of nicotine gum. European Journal of Clinical Investigation 29 145-152.

Ericsson UB \& Lindgrade F 1991 Effect of cigarette smoking on thyroid function and the prevalence of goitre, thyrotoxicosis and autoimmune thyroiditis. Journal of Internal Medicine 229 67-71.

Escobar-Morreale HF, Escobar del Rey F \& Morreale de Escobar G 1997 Thyroid hormones influence serum leptin concentrations in the rat. Endocrinology 138 4485-4488.

Fagundes AT, Moura EG, Passos MCF, Oliveira E, Toste FP, Bonomo IT, Trevenzoli IH, Garcia RMG \& Lisboa PC 2007 Maternal low-protein diet during lactation programmes body composition and glucose homeostasis in the adult rat offspring. British Journal of Nutrition 98 922-928.

Fisher CL, Mannino DM, Herman WH \& Frumkin H 1997 Cigarette smoking and thyroid hormone levels in males. International Journal of Epidemiology 26 972-977.

Friedman JM \& Halaas JL 1998 Leptin and the regulation of body weight in mammals. Nature 395 763-770.

Fukata S, Kuma K \& Sugawara M 1996 Relationship between cigarette smoking and hypothyroidism in patients with Hashimoto's thyroiditis. Journal of Endocrinological Investigation 19 607-612.

Gao YJ, Holloway AC, Zeng ZH, Lim GE, Petrik JJ, Foster WG \& Lee RM 2005 Prenatal exposure to nicotine causes postnatal obesity and altered perivascular adipose tissue function. Obesity Research 13 687-692.

Gasparoni A, Autelli M, Ravagni-Probizer MF, Bartoli A, Regazzi-Bonora M, Chirico G \& Rondini G 1998 Effect of passive smoking on thyroid function in infants. European Journal of Endocrinology 138 379-382.

Goldani MZ, Haeffner LSB, Agranonik M, Barbieri MA, Bettiol H \& Silva AAM 2007 Do early life factors influence body mass index in adolescents? Brazilian Journal of Medical and Biological Research 40 1231-1236.

Grun F \& Blumberg B 2006 Environmental obesogens: organotins and endocrine disruption via nuclear receptor signaling. E ndocrinology 147 S50-S55.

Hodge AM, Westerman RA, de Courten MP, Collier GR, Zimmet PZ \& Alberti KG 1997 Is leptin sensitivity the link between smoking cessation and weight gain? International Journal of Obesity and Related Metabolic Disorders 21 50-53.

Karakaya A, Tuncel N, Alptuna G, Kocer Z \& Erbay G 1987 Influence of cigarette smoking on thyroid hormone levels. Human Toxicology 6 507-509.

Von Kries R, Toschke AM, Koletzko B \& Slikker W Jr 2002 Maternal smoking during pregnancy and childhood obesity. American Journal of Epidemiology 156 954-961.

Lauberg P, NØHR SB, Pedersen KM \& Fuglsang EJ 2004 Iodine nutrition in breast-fed infants is impaired by maternal smoking. Journal of Clinical Endocrinology and Metabolism 89 181-187.

Levine ED, Morgan MM, Galvez C \& Ellison GD 1987 Chronic nicotine and withdrawal effects on body weight and food and water consumption in female rats. Physiology \& Behavior 39 441-444.

Li MD, Kane JK, Parker SL, McAllen K, Matta SG \& Sharp BM 2000 Nicotine administration enhances NPY expression in the rat hypothalamus. Brain Research 157164.

Lichtensteiger W, Ribary U, Schlumpf M, Odermatt B \& Widmer HR 1988 Prenatal adverse effects of nicotine on the developing brain. Progress in Brain Research 73 137-157.

Lins MC, Passos MC, Lisboa PC, Bonomo IT \& de Moura EG 2005 Leptin treatment during lactation increases transfer of iodine through the milk. Journal of Nutritional Biochemistry 16 138-143.

Lisboa PC, Oliveira KJ, Cabanelas A, Ortiga-Carvalho TM \& Pazos-Moura CC 2003 Acute cold exposure, leptin, and somatostatin analog (octreotide) modulate thyroid 5'-deiodinase activity. American Journal of Physiology. Endocrinology and Metabolism 284 E1172-E1176. 
Lisboa PC, Fagundes AT, Denolato AT, Oliveira E, Bonomo IT, Alves SB, Curty FH, Passos MC \& Moura EG 2008 Neonatal low-protein diet changes deiodinase activities and pituitary TSH response to TRH in adult rats. Experimental Biology and Medicine 233 57-63.

Livadas S, Magiakou MA, Mengreli C, Girginoudis P, Calani C, Smyruaki P, Kanaka-Gantenbein C, Xekouki P, Chrousos GP \& Dacou-Voutetakis C 2007 Obesity and attenuated adiposity rebound in children with congenital hypothyroidism. Normalization of BMI values in adolescents. Harmone and Metabolic Research 39 524-528.

Lowry OH, Roseberough NJ, Farr AL \& Randal RJ 1951 Protein measurement with the Folin phenol reagent. Journal of Biological Chemistry 193 265-275.

Lucas A 1994 Role of nutritional programming in determining adult morbidity. Archives of Disease in Childhood 71 288-290.

Maroni P, Bendinelli P \& Piccoletti R 2003 Early intracellular events induced by in vivo leptin treatment in mouse skeletal muscle. Molecular and Cellular Endocrinology 201 109-121.

McBride CM \& Pirie PL 1990 Postpartum smoking relapse. Addictive Behaviors 15 165-168.

Meberg A \& Marstein S 1986 Smoking during pregnancy - effects on the fetal thyroid function. Acta Paediatrica Scandinavica 75 762-766.

Morley R, Leeson Payne C, Lister G \& Lucas A 1995 Maternal smoking and blood pressure in 7.5 to 8 year old offspring. Archives of Disease in Childhood $72120-124$.

Mott GE, Lewis DS \& McGill HC Jr 1991 Programming of cholesterol metabolism by breast or formula feeding. Ciba Foundation Symposium 156 56-66.

Moura EG \& Passos MC 2005 Neonatal programming of body weight regulation and energetic metabolism. Bioscience Reports 25 251-269.

de Moura EG, Lisboa PC, Custodio CM, Nunes MT \& de Picoli Souza K 2007 Malnutrition during lactation changes growth hormone mRNA expression in offspring at weaning and in adulthood. Journal of Nutritional Biochemistry 18 134-139.

de Moura EG, Lisboa PC \& Passos MC 2008 Neonatal programming of neuroimmunomodulation - role of adipocytokines and neuropeptides. Neuroimmunomodulation 15 176-188.

Muller B, Zulewski H, Huber P, Ratcliffe JG \& Staub JJ 1995 Impaired action of thyroid hormone associated with smoking in women with hypothyroidism. New England Journal of Medicine 333 964-969.

Narayanan U, Birru S, Vaglenova J \& Breese CR 2002 Nicotinic receptor expression following nicotine exposure via maternal milk. Neuroreport 13 961-963.

Navarro HA, Seidler FJ, Schwartz RD, Baker FE, Dobbins SS \& Slotkin TA 1989 Prenatal exposure to nicotine impairs nervous system development at a dose which does not affect viability or growth. Brain Research Bulletin $\mathbf{2 3}$ $187-192$.

Newman MB, Shytle RD \& Sanberg PR 1999 Locomotor behavioral effects of prenatal and postnatal nicotine exposure in rat offspring. Behavioural Pharmacology 10 699-706.

Nicklas BJ, Tomoyasu N, Muir J \& Goldberg AP 1999 Effects of cigarette smoking and its cessation on body weight and plasma leptin levels. Metabolism 48 804-808.

O'Campo P, Faden RR, Brown H \& Gielen AC 1992 The impact of pregnancy on women's prenatal and postpartum smoking behavior. American Journal of Preventive Medicine 8 8-13.

Oliveira E, Fagundes AT, Alves SB, Pazos-Moura CC, Moura EG, Passos MC \& Lisboa PC 2007 Chronic leptin treatment inhibits liver mitochondrial alpha-glycerol-beta-phosphate dehydrogenase in euthyroid rats. Hormone and Metabolic Research 39 867-870.

De Oliveira E, Fagundes ATS, Bonomo IT, Curty FH, Passos MCF, De Moura EG \& Lisboa PC 2007 Acute and chronic leptin effect upon in vivo and in vitro rat thyroid iodide uptake. Life Sciences 81 1241-1246.

Ortiga-Carvalho TM, Oliveira KJ, Soares BA \& Pazos-Moura CC 2002 Leptin role in the regulation of thyrotropin secretion in fed state - in vivo and in vitro studies. Journal of Endocrinology 174 121-125.

Passos MC, da Fonte Ramos C, Dutra SC, Mouço T \& de Moura EG 2002 Long-term effects of malnutrition during lactation on the thyroid function of offspring. Hormone and Metabolic Research 34 40-43.

Passos MC, Vicente LL, Lisboa PC \& de Moura EG 2004 Absence of anorectic effect to acute peripheral leptin treatment in adult rats whose mothers were malnourished during lactation. Hormone and Metabolic Research 36 625-629.

Passos MC, Lins MC, Lisboa PC, Toste FP, Bonomo IT \& de Moura EG 2007 Maternal leptin treatment during lactation programs the thyroid function of adult rats. Life Sciences 80 1754-1758.

Perron B, Rodriguez AM, Leblanc G \& Pourcher T 2001 Cloning of the mouse sodium iodide symporter and its expression in the mammary gland and other tissues. Journal of Endocrinology 170 185-196.

Pontikides N \& Krassas GE 2007 Basic endocrine products of adipose tissue in states of thyroid dysfunction. Thyroid 17 421-431.

Rosenbaum M, Murphy EM, Heymsfield SB, Matthews DE \& Leibel RL 2002 Low dose leptin administration reverses effects of sustained weightreduction on energy expenditure and circulating concentrations of thyroid hormones. Journal of Clinical Endocrinology and Metabolism 87 2391-2394.

Simões FC, Marques RG, Diestel CF, Caetano CER, Dinis APG, Horst NL, Nogueira Neto JF \& Portela MC 2007 Lipidic profile among rats submitted to total splenectomy isolated or combined with splenic autotransplant. Acta Cirúrgica Brasileira 22 46-51.

Steinberg GR \& Dyck DJ 2000 Development of leptin resistance in rat soleus muscle in response to high-fat diets. American Journal of Physiology. Endocrinology and Metabolism 279 E1374-E1382.

Symonds ME 2007 Integration of physiological and molecular mechanisms of the developmental origins of adult disease: new concepts and insights. PNAS 66 442-450.

Tabb MM \& Blumberg B 2006 New modes of action for endocrinedisrupting chemicals. Molecular Endocrinology 20 475-482.

Tannenbaum GS, Gurd W \& Lapointe M 1998 Leptin is a potent stimulator of spontaneous pulsatile growth hormone $(\mathrm{GH})$ secretion and the $\mathrm{GH}$ response to GH-releasing hormone. Endocrinology 139 3871-3875.

Toschke AM, Koletzko B, Slikker W Jr, Hermann M \& von Kries R 2002 Childhood obesity is associated with maternal smoking in pregnancy. European Journal of Pediatrics 161 445-448.

Toste FP, de Moura EG, Lisboa PC, Fagundes AT, de Oliveira E \& Passos MC $2006 a$ Neonatal leptin treatment programmes leptin hypothalamic resistance and intermediary metabolic parameters in adult rats. British Journal of Nutrition 95 830-837.

Toste FP, Alves SB, Dutra SC, Bonomo IT, Lisboa PC, Moura EG \& Passos MC $2006 b$ Temporal evaluation of the thyroid function of rats programmed by leptin treatment on the neonatal period. Hormone and Metabolic Research 38 827-831.

Utiger RD 1998 Effects of smoking on thyroid function. European Journal of Endocrinology 138 368-369.

Vicente LL, de Moura EG, Lisboa PC, Monte Alto Costa A, Amadeu T, Mandarim-de-Lacerda CA \& Passos MC 2004 Malnutrition during lactation in rats is associated with higher expression of leptin receptor in the pituitary of adult offspring. Nutrition 20 924-928.

Vik T, Jacobsen G, Vatten L \& Bakketeig LS 1996 Pre- and post-natal growth in children of women who smoked in pregnancy. Early Human Development $19245-255$

Wang J, Liu R, Hawkins M, Barzilai N \& Rossetti L 1998 A nutrient-sensing pathway regulates leptin gene expression in muscle and fat. Nature 393 684-688.

Wei M, Stern MP \& Haffner SM 1997 Serum leptin levels in Mexican Americans and non-Hispanic whites: association with body mass index and cigarette smoking. Annals of Epidemiology 7 81-86.

Wideroe M, Vik T, Jacobsen G \& Bakketeig LS 2003 Does maternal smoking during pregnancy cause childhood overweight? Paediatric and Perinatal Epidemiology 17422.

Williams CM \& Kanagasabai T 1984 Maternal adipose tissue response to nicotine administration in the pregnant rat: effects on fetal body fat and cellularity. British Journal of Nutrition 51 7-13.

Received in final form 18 June 2009

Accepted 23 June 2009

Made available online as an Accepted Preprint 23 June 2009 